DEMOGRAPHIC RESEARCH

VOLUME 38, ARTICLE 5, PAGES 127-154

PUBLISHED 10 JANUARY 2018

http://www.demographic-research.org/Volumes/Vol38/5/

DOI: 10.4054/DemRes.2018.38.5

Research Article

Integrating occupations: Changing occupational sex segregation in the United States from 2000 to 2014

Patricia A. Roos

Lindsay M. Stevens

(C) 2018 Patricia A. Roos \& Lindsay M. Stevens.

This open-access work is published under the terms of the Creative Commons Attribution 3.0 Germany (CC BY 3.0 DE), which permits use, reproduction, and distribution in any medium, provided the original author(s) and source are given credit.

See https://creativecommons.org/licenses/by/3.0/de/legalcode. 


\section{Contents}

1 Introduction 128

2 Historical trends in feminization and masculinization 129

3 The 'how' of integration 130

4 The unevenness of integration 131

$5 \quad$ Data and methods $\quad 132$

$\begin{array}{lll}5.1 & \text { Data } & 132\end{array}$

$\begin{array}{lll}5.2 & \text { Variables } & 134\end{array}$

6 Analysis $\quad 135$

6.1 Changing occupational integration, 2000 to 2014

6.2 The social demography of feminizing and masculinizing occupations 141

6.3 Who works in feminizing vs. masculinizing occupations? 143

$\begin{array}{lll}7 & \text { Discussion } & 147\end{array}$

8 Acknowledgements 150

$\begin{array}{ll}\text { References } & 151\end{array}$ 


\title{
Integrating occupations: \\ Changing occupational sex segregation in the United States from 2000 to 2014
}

\author{
Patricia A. Roos ${ }^{1}$ \\ Lindsay M. Stevens ${ }^{2}$
}

\begin{abstract}
BACKGROUND

Declining occupational sex segregation in the late $20^{\text {th }}$ century helped to usher in unprecedented occupational and economic advancement for women. As the $21^{\text {st }}$ century dawned, that advancement stalled.
\end{abstract}

\section{OBJECTIVE}

We examine how occupational integration occurred in the early decades of the $21^{\text {st }}$ century by focusing on (1) the extent of occupational feminization and masculinization and (2) occupational succession. More broadly we examine how the representation of women in detailed occupational categories changed between 2000 and 2014, regardless of whether they were historically 'male' or 'female,' and how sociodemographic characteristics contributed to uneven shifts in occupational integration.

\section{METHODS}

We use Integrated Public Use Microdata Series data to estimate the percentage point female at the detailed occupation level, specifically the 5\% census microdata sample for 2000, and two 1\% American Community Survey (ACS) samples for 2013 and 2014.

\section{RESULTS}

Despite a stall in overall integration, there was much fluctuation within detailed occupations. Moreover, occupational inroads have been uneven in the post-2000 period. Women gained entry into the same types of professional and managerial occupations they entered between 1970 and 2000, especially in the health professions. Men increased their representation in lower-level, nonprofessional occupations.

\footnotetext{
${ }^{1}$ Corresponding author. Department of Sociology, Rutgers University, New Brunswick, USA. Email: roos@rutgers.edu.

${ }^{2}$ Department of Sociology, Rutgers University, New Brunswick, USA. Email: lindsay.stevens@rutgers.edu.
} 


\section{CONTRIBUTION}

Rather than focus solely on predominantly male or female occupations, we focus more broadly on how occupations feminize and masculinize. More occupations masculinized than previously. Moreover, those in feminizing occupations are more likely to be advantaged (e.g., white, citizens, and educated), while those in masculinizing occupations are more likely to be disadvantaged (e.g., black, Hispanic, and poor English speakers).

\section{Introduction}

Researchers, policy makers, and the general public have long been interested in why women and men continue to work in such different occupations. Stark occupational segregation by sex has endured for as long as statistics have been kept. We remain interested in this topic because occupational sex segregation is shorthand for gender inequity in women's opportunities, both occupationally and economically. It was not until the 1970s that overall sex segregation began to decline in any substantial way. That decline continued more slowly in the 1980s and 1990s due in large measure to women's inroads into traditionally male occupations, especially in professional and managerial fields. Occupational integration has long been seen as a boon for women's occupational and economic advancement (Cohen 2013; Hegewisch and Hartmann 2014; Mandel 2013; Reskin and Roos 1990). Indeed, Blau and Kahn (2016) argue that gender differences in occupational distribution remain the most important explanation for the remaining wage gap.

As the new century dawned, researchers began to report on a stall in overall occupational sex desegregation, relying for the most part on indexes of dissimilarity (Cotter, Hermsen, and Vanneman 2004, 2009; Cohen, Huffman, and Knauer 2009; England 2010; Hegewish and Hartmann 2014; Tomaskovic-Devey et al. 2006). ${ }^{3}$ For example, from 1950 to 1990 there were steep declines in occupational segregation: The indexes declined from 60.8 to 48.4. Between 1990 and 2000 there was a smaller decline, from 48.4 to 46.6 , meaning that by 2000 about $47 \%$ of workers would need to switch occupations for men and women to be represented equally (Cotter, Hermsen, and Vanneman 2004: Table 6).

We know substantially less about what has happened since the stall began, although this recent period is of great interest to the popular press (e.g., Dewan and

\footnotetext{
${ }^{3}$ Researchers focus on multiple types of stalls when discussing trends in gender inequality (e.g., in labor force participation, occupational sex segregation, and earnings [Cotter, Hermsen, and Vanneman 2004; England 2010]). We focus here on declining occupational sex segregation, or occupational integration.
} 
Gebeloff 2012; Miller 2017). In this paper, we explore how sex integration shifted in recent decades. Rather than using indexes of dissimilarity, we follow a different tradition in integration research, focusing on how the representation of women in detailed occupational categories changed between 2000 and 2014 (e.g., Reskin and Roos 1990). Traditionally, researchers have studied predominantly male occupations that feminized. We examine masculinization as well. More broadly, we examine how occupations shifted to become more or less segregated by sex, regardless of whether those occupations were initially 'male' or 'female.' We also examine how the integration occurred by focusing on its unevenness, specifically by sociodemographic characteristics such as race and immigrant status (e.g., Dill, Price-Glynn, and Rakovski 2016; Gatta and Roos 2005). With these foci we examine sex integration in process.

\section{Historical trends in feminization and masculinization}

Since the 1970s, significant changes in occupational structure, and culture and attitudes more broadly (e.g., Coontz 2011), increased women's representation in the labor force, and increased their inroads into male occupations (Hegewisch and Hartmann 2014; Mandel 2013; Reskin and Roos 1990). At the aggregate level, by 1970 women made up $38 \%$ of the workforce. By 1980, their overall percentage increased by $4.6 \%$ (to $42.6 \%$ ), and another $2.4 \%$ by 1988 (to 45\%; Reskin and Roos 1990: Table 1.6). Mandel (2013: Table 1) finds that increased female representation between 1970 and 2007 reflected their inroads into high-paid occupations: By 2007 their representation in the top wage decile was nearly equal to men's. Our data shows that between 2000 and 2014, women's representation at the aggregate level slowed to less than one half of one percentage point ( $+.35 \%$ ), from 47.93 to $48.28 \%$, another form of stall.

In the 1970 to 1990 period, occupational feminization occurred more frequently than masculinization (occupations disproportionately increasing vs. decreasing their representation of women respectively). Reskin and Roos (1990: Table 1.6) show that 33 traditionally male occupations ( $>60 \%$ male in 1970) feminized disproportionately between 1970 and 1980 . In contrast, only three traditionally female occupations ( $>60 \%$ female in 1970) masculinized disproportionately. ${ }^{4}$ Following a similar logic for mixedsex occupations, Gatta and Roos (2005: Table II) find that 37 occupations feminized

\footnotetext{
${ }^{4}$ Reskin and Roos's (1990) figures are calculated using a detailed occupational classification comparable across the three decades studied. Their (p. 16) criterion for "disproportionate change" was $9 \%$ or more, or roughly twice women's change in the labor force as a whole from 1970 to $1980(4.6 \%)$. The 33 traditionally male occupations that disproportionately feminized were chosen from 503 detailed occupations. Reskin and Roos's (1990: 27) endnotes 13 and 15 make clear that their Table 1.6 refers only to occupations designated as predominantly male or female (more than $60 \%$ male or female respectively) in 1970 .
} 
disproportionately between 1970 and 1990, nine remained stable, and only four disproportionately masculinized. ${ }^{5}$

Because most of the occupational sex integration that occurred between 1970 and 1990 was women moving into traditionally male occupations, researchers focus on the conditions, barriers, and stimuli to women's advancement in these occupations (e.g., Reskin and Roos 1990). Other researchers (e.g., Williams 1993) examine male entry into female occupations, especially the female professions. Here we study broader processes of feminization and masculinization across the occupational spectrum, not just predominantly male occupations that feminized or predominantly female occupations that masculinized.

\section{The 'how' of integration}

As noted, we follow in the tradition of integration research that uses change in occupational percentage point female to demonstrate how feminization and masculinization occur. Relying on a set of case studies of traditionally male occupations that feminized in the 1970s, Reskin and Roos (1990) posit a dual queuing approach to demonstrate how occupational integration operates, addressing issues of both supply and demand. Although their main interest was in explaining occupational feminization, their logic holds for masculinization as well. Importantly, they describe the changing representation of women in the context of occupational succession, or how occupational integration was patterned by sex, race, and immigrant status. For example, they describe how in the 1800s Irish men replaced native white women in the United States textile mills as the latter moved to middle-class jobs like teaching that white men were leaving. Cigar making also shifted from female to male and back to female again, as the location of work shifted from home to the factory, and from less to more skilled, and back to less skilled again (page 15). Also focusing on a historical view, Branch (2011) describes how structural mechanisms led to variations in integration by race, sex, and class. Using an intersectional lens, she demonstrates how employers relied on a "hierarchy of preferences" to choose among race and sex groups.

In their study of mixed occupations (those between $45 \%$ and $55 \%$ female in 1990), Gatta and Roos (2005: 370) demonstrate the theoretical usefulness of studying how "nominally integrated" occupations increased or decreased their representation of women. Their findings show that "paths to equity" vary within currently mixed occupations: Some integrated occupations feminized between 1970 and 1990, and a much smaller number masculinized or remained stable (2005: Table II). They also

${ }^{5}$ Gatta and Roos (2005) use the same data and classification as Reskin and Roos, for 1970, 1980, and 1990. Their criterion for disproportionate change was 10\% or more between 1970 and 1990 . 
addressed occupational succession, demonstrating empirically how occupational integration was patterned by race, immigration status, and other sociodemographic characteristics.

\section{The unevenness of integration}

Much of the rich research on the unevenness of integration addresses occupational choice, a focus not possible with our data. Instead we examine how occupational outcomes are patterned by race and other sociodemographic characteristics. Such sociodemographic unevenness suggests that it is important to examine more recent data, and to do so in an intersectional way (e.g., Browne and Misra 2003; McCall 2005).

Our data demonstrates that women's representation in the labor force only increased by $+.35 \%$ between 2000 and 2014. As Reskin and Maroto (2011: 82) argue, "It makes sense to look at which groups advanced most and least and in what sectors." This unevenness in sex integration suggests that the observed stall at the aggregate level will likely vary across occupations. Accordingly, we examine the extent to which women's representation shifts at the detailed occupational level. We expect to see variation by race and other sociodemographic characteristics (e.g., citizenship, immigrant status, English language proficiency, and poverty), similar to those Gatta and Roos (2005) find for earlier years. Researchers demonstrate the importance of demographic factors other than gender on occupational mobility. Alegria and Branch (2015) show that focusing solely on gender oversimplifies the role of race and immigrant status on career success in US STEM fields. Dill, Price-Glynn, and Rakovski (2016) demonstrate the importance of racial/ethnic status on men's participation in predominantly female direct health care work. Finally, Cotter, Hermsen, and Vanneman (2004) confirm variation across race/ethnic groups in occupational integration.

We expect feminization of traditionally male professions to continue, reflecting declines in sex gaps in education and experience. Using data for 1980 to 2010, Blau and Kahn (2016) find that women increased both their educational attainment and their labor market experience relative to men. Indeed, by 2011, women's average level of schooling was higher than men's, and they were more likely than men to have at least an advanced degree (page 4; see also Buchmann, DiPrete, and McDaniel 2008).

Autor (2010: 203, Figure 1) also demonstrates significant shifts in the broader economy for 1979 to 2007: He finds a "pronounced 'polarization' of job opportunities across occupations, with employment growth concentrated in relatively high-skill, highwage and in low-skill, low-wage jobs - at the expense of 'middle-skill' jobs." Declining middle-skill occupations include blue-collar production, craft, and operative work, precisely the occupations held by male workers without a college degree (Autor 2010: 
1; see also Dill, Price-Glynn, and Rakovski 2016). Although these employment declines in middle-skill occupations were substantially greater for women than men (Autor 2010: 10), women were more likely to move from middle- to high-skill occupations, while men moved to the "tails of the distribution," especially low-skill occupations. These findings illustrate the hollowing out of the middle class (Kalleberg 2009, 2011; Williams 2013), suggesting continued shifts of educated women into professional occupations and men into low-skill occupations.

We address two research questions. First, does the stall in sex integration at the aggregate level persist throughout the occupational structure? We examine which detailed occupations disproportionately feminized and masculinized between 2000 and 2014 and whether earlier patterns of integration continued or shifted over time. Second, we examine occupational succession, specifically focusing on the social demography of occupational change: Who works in feminizing and masculinizing occupations respectively? By focusing broadly we are able to identify sex integration in process, even if those occupations have not yet shifted their composition to predominantly male or female occupations, and indeed perhaps never will.

\section{Data and methods}

\subsection{Data}

We examine changing occupational sex segregation from 2000 to 2014 using microdata for detailed occupational categories available from Integrated Public Use Microdata Series (IPUMS)(Ruggles et al. 2015; https://usa.ipums.org/usa/sda/). For 2000, we use the $5 \%$ census microdata sample. To generate a sufficient sample size for 2014 , we combined two 1\% American Community Survey (ACS) samples, 2013 and 2014, referring to the two latter as 2014.

We chose to focus on the 2000 to 2014 period. First, previous work has already thoroughly examined the pre-2000 period (e.g., Gatta and Roos 2005; Reskin and Roos 1990). Our work examines whether those earlier patterns persist or change. Second, there were major changes in the census occupational classifications that occurred between 1970 and 2000 and still more changes between 2000 and 2014. Reskin and Roos (1990) and Gatta and Roos (2005) use the same, comparable data for 1970, 1980, and 1990; we address comparability issues between 2000 and 2014 (see below). Third, with the 2013 and 2014 ACS data, we use the most recent data available with detailed occupational data. 
With respect to sample selection, we use all those for whom a detailed occupational code was available. ${ }^{6}$ The age range for this selection was 16 to 93 in 2000, and 16 to 96 in 2014. We weighted our analyses by the recommended IPUMS weight variable (perwt for 2000, and perwt/2 for 2013/2014). We spent considerable time assessing the comparability between the 2000 and 2014 detailed occupational classifications and created a comparable four-digit code (occ2014). ${ }^{7}$ We feel confident in our comparisons, given that all the occupational classifications are based on detailed US data.

Our analytic strategy presents data at both the occupational and individual levels addressing our two research questions. In Table 1 we examine which detailed occupations disproportionately shifted their sex composition between 2000 and 2014 . To compare our findings with previous decades, we calculated the detailed occupation's sex type in 2000. This variable was coded 'male' when the percent female in 2000 was less than $40 \%$, 'mixed' when it was inclusive $40 \%-60 \%$, and 'female' when it was greater than $60 \%$. We then address the social demography of occupational change: Who works in feminizing vs. masculinizing occupations? ${ }^{8}$ We estimate descriptive statistics for occupational characteristics typically addressed in analyses of this sort, and determine if these vary by feminizing, stable, and masculinizing occupations (Table 2). Turning to individual-level data, we then estimate a logistic regression to determine which sociodemographic characteristics lead to masculinization and which to feminization between 2000 and 2014 (Tables 3 and 4). Our estimates are calculated for samples with no missing values on included variables.

\footnotetext{
${ }^{6}$ There are two exceptions to this general rule: (1) we excluded anyone who was unemployed with no work experience in the last five years or earlier or never worked, and (2) we excluded anyone in occupations that could not be made comparable between 2000 and 2014 .

${ }^{7}$ We were successful in creating an occupational classification with a large number of comparable codes $(\mathrm{n}=448)$, with 475 codes in 2000, and 478 codes in 2014. An appendix that shows our decision making is available upon request. We specify the 2000 codes and names, the 2014 codes and names, our new code based on the 2014 OCC code ("occ2014"), the percentage female for each year calculated with occ2014 codes, and the change in percentage female between 2000 and 2014. We use several reference documents to create "occ2014": https://usa.ipums.org/usa/resources/codebooks/2000_PUMS_codebook.pdf, https://usa.ipu ms.org/usa/volii/occ_acs.shtml, and https://usa.ipums.org/usa/volii/acs_occtooccsoc.shtml.

${ }^{8}$ We use 'feminized' and 'masculinized' to refer to changing occupational sex composition (e.g., 'sex type'), not occupational gender type. See Britton (2000: 424) for a discussion of the distinction between these concepts.
} 


\subsection{Variables}

Our first order of business was to calculate a measure of occupational integration, which we use as our major differentiating independent variable in Table 2, and then as a dependent variable in Tables 3 and 4 . We first coded whether the respondents were in occupations that feminized, remained stable, or masculinized between 2000 and 2014, and then aggregated individuals into occupations. As noted, we determined whether an occupation masculinized or feminized by looking at the overall change in female representation between 2000 and 2014: We coded a person as being in a masculinizing occupation when the representation of women declined by at least four percentage points and as being in a feminizing occupation when the representation of women increased by at least four percentage points. All other occupations were labeled as stable. We chose a four-percentage-point cutoff, which was approximately ten times the overall change of $+.35 \%{ }^{9}$ For the descriptive analysis, we use the three-category integration variable (Table 2). We simplified the multivariate analysis (Tables 3 and 4) by looking only at those occupations that changed disproportionately. Thus we recoded integration as 1 for those in a masculinizing occupation and 0 for those in a feminizing occupation.

We chose other variables that were both available in the data and that researchers typically examine. We focus on race and immigrant status, but look more broadly at a range of demographic and work variables. We use these as dependent variables in the descriptive analysis (to determine how occupational integration affected occupational characteristics in 2014), and as independent variables in the multivariate analysis (to determine at the individual level how occupational characteristics predict placement in masculinizing vs. feminizing occupations in 2014). Several variables were coded 0/1: Hispanic, citizen, foreign-born, poor English speaking ability, poverty, professional/manager work, worked for wages during reference day/week (vs. selfemployed), usually worked 35 or more hours per week in the previous year, and worked 50 to 52 weeks in the previous year (see Tables 3 and 4). Age was coded in years. Three variables were recoded and estimated as dummy variables: (1) marital status (married spouse present [the reference category], formerly married/separated, and never married); (2) race (white [the reference category], black, and other [including those who

\footnotetext{
${ }^{9}$ We chose the criterion of $4 \%$ to be consistent with how previous researchers define 'disproportionate.' Reskin and Roos's (1990) and Gatta and Roos's (2005) larger cut points of 9\% or 10\% respectively make sense given the substantially greater flux in occupational percentage point female between 1970 and 1990. To determine whether our lower cut point would substantially change our results, we reran our Tables 1 and 2 with a cut point of a seven-percentage-point change (or 20 times the $+.35 \%$ change between 2000 and 2014). Not surprisingly, the number of occupations categorized as disproportionate declined. Reassuringly, however, our substantive results were quite similar to those for our four-percentage-point cutoff. We include these results where appropriate below.
} 
indicate multiple races]); and (3) education (less than high school, high school or some college, and four years or more of college [reference category]). Measurement is selfexplanatory in the variable name, as indicated on the tables.

To examine the unevenness of integration by race and sex, we undertook an intersectional analysis. We conducted multivariate analyses within sex, predicting sex integration (Tables 3 and 4). We considered creating dummy variables for race-sex groups (e.g., white women, black women, and other race men) or dummy variables for race-sex-Hispanic groups (e.g., white Hispanic women, black non-Hispanic men, and other race Hispanic women). Such comparisons would quickly get cumbersome (e.g., six dummy variables for the first set and 12 in the second) and indeed would not present the most substantively interesting comparisons. Instead, like Williams and Villemez (1993) and Dill, Price-Glynn, and Rakovski (2016), we use race and other characteristics to predict which men (and then women) are in masculinizing vs. feminizing occupations.

\section{Analysis}

\subsection{Changing occupational integration, 2000 to 2014}

Turning to our first research question, we ask which detailed occupations disproportionately changed their percentage point female between 2000 and 2014. Of the 448 occupations for which we had comparable occupation codes, Table 1 lists the 123 occupations (or more than one-quarter of all detailed occupations) that disproportionately changed their sex composition by at least $4 \%$ between 2000 and 2014. This data suggests that despite the small, overall change in percent female $(+.35$ percentage points), there was substantial flux within detailed occupations over the 14year period. This fluctuation occurs throughout the occupational spectrum, from managerial and professional occupations to protective service work, sales, administrative support, skilled production work, and other blue-collar work. 
Roos \& Stevens: Changing occupational sex segregation in the United States from 2000 to 2014

\section{Table 1: Occupations with disproportionate change in percentage point female between 2000 and 2013-2014, organized by feminizing and masculinizing occupations ${ }^{\mathrm{a}}$}

\begin{tabular}{|c|c|c|c|c|}
\hline Occupation title (Revised 2014 Occupational Code) $(n=123)$ & $\begin{array}{l}\% \text { female } \\
2000\end{array}$ & $\begin{array}{l}\text { \% female } \\
2013-2014\end{array}$ & $\begin{array}{l}\% \text { female } \\
\text { change }\end{array}$ & $\begin{array}{l}\text { 2013-2014 } \\
\text { (Sample N) }\end{array}$ \\
\hline $\begin{array}{l}\text { All occupations with disproportionate change in percentage point } \\
\text { female }\end{array}$ & 47.93 & 48.21 & 0.27 & $35,166,084$ \\
\hline Feminizing occupations $(n=62)$ & 46.10 & 53.12 & 7.02 & $13,250,877$ \\
\hline Male Occupations $(<40 \%$ female in 2000$)(n=41)$ & $\underline{25.63}$ & $\underline{32.74}$ & $\underline{7.11}$ & $\underline{9,469,232}$ \\
\hline Chief executives and legislators $^{b}(10)$ & 19.75 & 24.92 & 5.17 & $1,367,474$ \\
\hline General and operations managers $(20)$ & 26.52 & 30.68 & 4.16 & $1,081,070$ \\
\hline Industrial production managers $(140)$ & 16.38 & 20.53 & 4.15 & 270,287 \\
\hline Natural sciences managers $(360)$ & 32.38 & 50.97 & 18.59 & 20,453 \\
\hline Buyers and purchasing agents, farm products ${ }^{\mathrm{b}}(510)$ & 23.03 & 28.28 & 5.25 & 11,176 \\
\hline $\begin{array}{l}\text { Human resources workers; compensation, benefits, and job } \\
\text { analysis specialists; training and development specialists (629) }\end{array}$ & 64.90 & 69.14 & 4.24 & $1,072,516$ \\
\hline Financial analysts (840) & 32.72 & 38.29 & 5.57 & 156,760 \\
\hline Architects, except naval (1300) & 21.11 & 26.80 & 5.69 & 207,744 \\
\hline Environmental engineers (1420) & 21.78 & 27.78 & 6.00 & 30,061 \\
\hline Industrial engineers, including health and safety (1430) & 16.84 & 20.93 & 4.09 & 212,363 \\
\hline Marine engineers and naval architects ${ }^{\mathrm{b}}(1440)$ & 5.49 & 9.94 & 4.45 & 14,758 \\
\hline Agricultural and food scientists (1600) & 26.36 & 36.00 & 9.64 & 30,176 \\
\hline Conservation scientists and foresters (1640) & 15.34 & 19.94 & 4.60 & 24,902 \\
\hline Atmospheric and space scientists (1710) & 12.36 & 17.33 & 4.97 & 13,188 \\
\hline Chemists and materials scientists (1720) & 33.21 & 37.50 & 4.29 & 94,137 \\
\hline Environmental scientists and geoscientists (1740) & 24.66 & 31.15 & 6.49 & 85,407 \\
\hline Physical scientists, all other (1760) & 35.98 & 40.92 & 4.94 & 231,151 \\
\hline Clergy $(2040)$ & 15.40 & 19.98 & 4.58 & 505,673 \\
\hline $\begin{array}{l}\text { Lawyer, judges, magistrates; judicial law clerks, and other } \\
\text { judicial workers }{ }^{c} \text { (2099) }\end{array}$ & 30.69 & 36.47 & 5.78 & $1,224,322$ \\
\hline Chiropractors $(3000)$ & 23.48 & 28.68 & 5.20 & 58,844 \\
\hline Dentists (3010) & 17.93 & 28.39 & 10.46 & 183,947 \\
\hline Optometrists (3040) & 27.41 & 40.99 & 13.58 & 39,527 \\
\hline Physicians and surgeons (3060) & 26.77 & 34.91 & 8.14 & 948,932 \\
\hline Podiatrists (3120) & 17.43 & 24.93 & 7.50 & 9,986 \\
\hline Veterinarians $(3250)$ & 39.76 & 55.32 & 15.56 & 81,652 \\
\hline Other healthcare practitioners and technical occupations (3540) & 37.78 & 43.05 & 5.27 & 110,956 \\
\hline First-line supervisors of correctional officers ${ }^{b}(3700)$ & 24.77 & 30.26 & 5.49 & 65,664 \\
\hline Detectives and criminal investigators $(3820)$ & 20.47 & 26.41 & 5.94 & 150,152 \\
\hline Animal control workers $(3900)$ & 34.36 & 43.60 & 9.24 & 13,918 \\
\hline Private detectives and investigators (3910) & 34.02 & 41.51 & 7.49 & 104,487 \\
\hline Motion picture projectionists (4410) & 14.31 & 19.80 & 5.49 & 7,095 \\
\hline Ushers, lobby attendants, and ticket takers (4420) & 31.32 & 44.52 & 13.20 & 71,880 \\
\hline $\begin{array}{l}\text { Miscellaneous entertainment attendants and related workers } \\
(4430)\end{array}$ & 38.00 & 42.19 & 4.19 & 315,503 \\
\hline
\end{tabular}


Table 1: (Continued)

\begin{tabular}{|c|c|c|c|c|}
\hline Occupation title (Revised 2014 Occupational Code) $(n=123)$ & $\begin{array}{l}\% \text { female } \\
2000\end{array}$ & $\begin{array}{l}\% \text { female } \\
2013-2014\end{array}$ & $\begin{array}{l}\% \text { female } \\
\text { change }\end{array}$ & $\begin{array}{l}\text { 2013-2014 } \\
\text { (Sample N) }\end{array}$ \\
\hline Baggage porters, bellhops, and concierges (4530) & 16.50 & 24.60 & 8.10 & 107,048 \\
\hline Cargo and freight agents $(5500)$ & 26.40 & 31.75 & 5.35 & 23,880 \\
\hline Postal service mail carriers $(5550)$ & 33.82 & 39.09 & 5.27 & 362,666 \\
\hline Agricultural inspectors $(6010)$ & 31.05 & 43.28 & 12.23 & 18,000 \\
\hline Hazardous materials removal workers $(6720)$ & 8.97 & 16.14 & 7.17 & 41,156 \\
\hline Print binding and finishing workers ${ }^{\mathrm{b}}(8256)$ & 34.40 & 46.07 & 11.67 & 30,222 \\
\hline Jewellers and precious stone and metal workers $(8750)$ & 31.60 & 39.76 & 8.16 & 50,073 \\
\hline $\begin{array}{l}\text { Conveyor operators and tenders, and hoist and winch operators }{ }^{b} \\
(9560)\end{array}$ & 5.52 & 9.72 & 4.20 & 20,026 \\
\hline Mixed occupations (between $40-60 \%$ female in 2000$)(n=14)$ & $\underline{47.12}$ & $\underline{53.54}$ & $\underline{6.42}$ & $\underline{3,079,546}$ \\
\hline Public relations and fundraising managers ${ }^{\mathrm{b}}(60)$ & 55.89 & 65.57 & 9.68 & 64,160 \\
\hline Purchasing managers (150) & 40.07 & 45.56 & 5.49 & 218,471 \\
\hline Financial examiners (900) & 42.64 & 49.16 & 6.52 & 14,420 \\
\hline Biological scientists $(1610)$ & 44.82 & 50.20 & 5.38 & 81,096 \\
\hline Medical scientists and life scientists, all other ${ }^{\mathrm{b}}(1650)$ & 47.22 & 53.10 & 5.88 & 156,196 \\
\hline Photographers $^{\mathrm{b}}(2910)$ & 41.82 & 50.62 & 8.80 & 222,052 \\
\hline Pharmacists (3050) & 46.49 & 55.27 & 8.78 & 315,720 \\
\hline Bartenders (4040) & 55.55 & 59.55 & 4.00 & 529,412 \\
\hline First-line supervisors of gaming workers (4300) & 40.83 & 45.21 & 4.38 & 60,198 \\
\hline Animal trainers $(4340)$ & 47.85 & 57.90 & 10.05 & 53,899 \\
\hline Insurance sales agents (4810) & 42.73 & 47.39 & 4.66 & 646,806 \\
\hline Production, planning, and expediting clerks (5600) & 53.31 & 57.74 & 4.43 & 383,621 \\
\hline Bakers $(7800)$ & 51.65 & 57.77 & 6.12 & 288,329 \\
\hline Prepress technicians and workers $(8250)$ & 48.84 & 54.57 & 5.73 & 45,166 \\
\hline Female occupations (>60\% female in 2000$)(n=7)$ & $\underline{65.53}$ & $\underline{73.07}$ & $\underline{7.54}$ & $\underline{702,099}$ \\
\hline Psychologists (1820) & 64.22 & 70.80 & 6.58 & 217,758 \\
\hline Other education, training, and library workers (2550) & 66.53 & 71.23 & 4.70 & 166,022 \\
\hline Physician assistants $(3110)$ & 63.62 & 68.29 & 4.67 & 131,522 \\
\hline Health diagnosing and treating practitioners, all other (3260) & 60.63 & 71.77 & 11.14 & 27,412 \\
\hline Opticians, dispensing (3520) & 66.00 & 73.82 & 7.82 & 64,864 \\
\hline Brokerage clerks $(5200)$ & 62.12 & 74.84 & 12.72 & 9,512 \\
\hline $\begin{array}{l}\text { Human resources assistants, except payroll and timekeeping } \\
(5360)\end{array}$ & 75.59 & 80.71 & 5.12 & 85,009 \\
\hline Masculinizing occupations $(n=61)$ & $\underline{49.77}$ & $\underline{43.30}$ & $\underline{-6.47}$ & $\underline{21,915,207}$ \\
\hline Male occupations $(<40 \%$ female in 2000$)(n=20)$ & $\underline{26.61}$ & $\underline{20.37}$ & $\underline{-6.24}$ & $\underline{5,194,955}$ \\
\hline Administrative services managers $(100)$ & 39.95 & 34.84 & -5.11 & 160,022 \\
\hline Computer programmers ${ }^{\mathrm{b}}(1010)$ & 28.46 & 22.69 & -5.77 & 509,763 \\
\hline Network and computer systems administrators (1199) & 31.86 & 26.90 & -4.96 & $1,181,264$ \\
\hline $\begin{array}{l}\text { Broadcasting and sound engineering technicians and radio } \\
\text { operators and media and communication equipment workers, all } \\
\text { others }^{\text {b }}(2900)\end{array}$ & 14.99 & 9.16 & -5.83 & 131,732 \\
\hline Couriers and messengers (5510) & 22.76 & 17.07 & -5.69 & 280,626 \\
\hline Engine and other machine assemblers $(7730)$ & 23.58 & 12.60 & -10.98 & 19,071 \\
\hline
\end{tabular}


Roos \& Stevens: Changing occupational sex segregation in the United States from 2000 to 2014

\section{Table 1: $\quad$ (Continued)}

\begin{tabular}{|c|c|c|c|c|}
\hline Occupation title (Revised 2014 Occupational Code) ( $n=123)$ & $\begin{array}{l}\% \text { female } \\
2000\end{array}$ & $\begin{array}{l}\text { \% female } \\
2013-2014\end{array}$ & $\begin{array}{l}\% \text { female } \\
\text { change }\end{array}$ & $\begin{array}{l}\text { 2013-2014 } \\
\text { (Sample N) }\end{array}$ \\
\hline Computer control programmers and operators (7900) & 13.33 & 8.22 & -5.11 & 97,349 \\
\hline $\begin{array}{l}\text { Machine tool cutting setters, operators, and tenders, metal and } \\
\text { plastic; cutting, punching, and press machine setters, operators, } \\
\text { and tenders, metal and plastic; drilling and boring tool setters, } \\
\text { operators, and tenders, metal and plastic; grinding, lapping, } \\
\text { polishing, and buffing machine tool setters, operators, and } \\
\text { tenders, metal and plastic }{ }^{\text {b }}(7950)\end{array}$ & 22.22 & 17.27 & -4.95 & 196,704 \\
\hline $\begin{array}{l}\text { Miscellaneous metal workers and plastic workers, including } \\
\text { milling and planing machine setters, and multiple machine tool } \\
\text { setters, and layout workers }{ }^{\text {b }}(8220)\end{array}$ & 28.39 & 21.52 & -6.87 & 507,363 \\
\hline $\begin{array}{l}\text { Shoe and leather workers and repairers; shoe machine } \\
\text { operators and tenders }{ }^{b}(8330)\end{array}$ & 39.31 & 32.59 & -6.72 & 19,404 \\
\hline Sewing machine setters, operators, and tenders, wood (8530) & 14.31 & 7.74 & -6.57 & 41,301 \\
\hline $\begin{array}{l}\text { Woodworking machine setters, operators, and tenders, except } \\
\text { sawing }(8540)\end{array}$ & 27.52 & 20.93 & -6.59 & 29,170 \\
\hline Cutting workers $(8710)$ & 29.29 & 25.16 & -4.13 & 89,291 \\
\hline $\begin{array}{l}\text { Extruding, forming, pressing, and compacting machine setters, } \\
\text { operators, and tenders (8720) }\end{array}$ & 25.96 & 21.71 & -4.25 & 38,560 \\
\hline $\begin{array}{l}\text { Furnace, kiln, oven, drier, and kettle operators and tenders } \\
(8730)\end{array}$ & 32.66 & 17.35 & -15.31 & 14,880 \\
\hline Painting workers $(8810)$ & 18.41 & 13.68 & -4.73 & 163,599 \\
\hline Etchers and engravers (8910) & 36.47 & 32.06 & -4.41 & 13,076 \\
\hline Molders, shapers, and casters, except metal and plastic (8920) & 22.43 & 16.57 & -5.86 & 40,644 \\
\hline $\begin{array}{l}\text { Other production workers, including semiconductor processors } \\
\text { and cooling and freezing equipment operators; production } \\
\text { workers, all others; other production workers including } \\
\text { semiconductor processors and cooling and freezing equipment } \\
\text { operators; cleaning, washing, and metal pickling equipment } \\
\text { operators and tenders }^{\mathrm{b}}(8965)\end{array}$ & 36.37 & 29.64 & -6.73 & $1,514,628$ \\
\hline Automotive and watercraft service attendants ${ }^{b}(9360)$ & 23.92 & 19.74 & -4.18 & 146,508 \\
\hline Mixed occupations (between $40-60 \%$ female in 2000$)(n=13)$ & $\underline{50.49}$ & $\underline{43.47}$ & $\underline{-7.02}$ & $\underline{6,712,542}$ \\
\hline Biological technicians (1910) & 54.06 & 41.16 & -12.90 & 27,552 \\
\hline News analysts, reporters and correspondents (2810) & 49.48 & 45.01 & -4.47 & 88,318 \\
\hline $\begin{array}{l}\text { Lifeguards and other recreational, and all other protective } \\
\text { service workers ( } 3955)\end{array}$ & 56.82 & 49.57 & -7.25 & 369,096 \\
\hline Cooks $(4020)$ & 45.78 & 41.58 & -4.20 & $3,138,177$ \\
\hline $\begin{array}{l}\text { First-line supervisors of housekeeping and janitorial workers }{ }^{D} \\
(4200)\end{array}$ & 43.32 & 38.43 & -4.89 & 274,385 \\
\hline Tour and travel guides $(4540)$ & 52.39 & 46.69 & -5.70 & 81,426 \\
\hline Computer operators $(5800)$ & 53.74 & 46.40 & -7.34 & 120,901 \\
\hline Miscellaneous assemblers and fabricators $(7750)$ & 45.85 & 38.57 & -7.28 & $1,349,571$ \\
\hline $\begin{array}{l}\text { Food cooking machine operators and tenders, food processing } \\
\text { workers, all other }{ }^{c}(7854)\end{array}$ & 47.80 & 35.42 & -12.38 & 168,260 \\
\hline $\begin{array}{l}\text { Miscellaneous textile, apparel, and furnishings workers, except } \\
\text { upholsterers (8460) }\end{array}$ & 52.65 & 46.09 & -6.56 & 24,750 \\
\hline
\end{tabular}


Table 1: (Continued)

\begin{tabular}{|c|c|c|c|c|}
\hline Occupation title (Revised 2014 Occupational Code) $(n=123)$ & $\begin{array}{l}\% \text { female } \\
2000\end{array}$ & $\begin{array}{l}\text { \% female } \\
2013-2014\end{array}$ & $\begin{array}{l}\% \text { female } \\
\text { change }\end{array}$ & $\begin{array}{l}\text { 2013-2014 } \\
\text { (Sample N) }\end{array}$ \\
\hline Inspectors, testers, sorters, samplers, and weighers (8740) & 47.68 & 39.35 & -8.33 & $1,004,284$ \\
\hline $\begin{array}{l}\text { Photographic process workers and processing machine } \\
\text { operators }(8830)\end{array}$ & 59.00 & 54.47 & -4.53 & 52,782 \\
\hline Adhesive bonding machine operators and tenders ${ }^{\mathrm{b}}(8850)$ & 47.84 & 42.41 & -5.43 & 13,040 \\
\hline Female occupations ( $>60 \%$ female in 2000$)(n=28)$ & $\underline{72.21}$ & $\underline{66.05}$ & $\underline{-6.16}$ & $\underline{10,007,710}$ \\
\hline Claims adjusters, appraisers, examiners, and investigators (540) & 64.96 & 60.05 & -4.91 & 334,030 \\
\hline Credit analysts (830) & 63.35 & 58.67 & -4.68 & 30,256 \\
\hline Religious workers, all other (2060) & 63.19 & 59.17 & -4.02 & 101,315 \\
\hline Radiation therapists (3200) & 72.31 & 64.79 & -7.52 & 18,634 \\
\hline Physical therapist assistants and aides (3620) & 76.11 & 71.44 & -4.67 & 92,273 \\
\hline Crossing guards $(3940)$ & 63.59 & 56.20 & -7.39 & 85,226 \\
\hline Transportation attendants (4550) & 79.70 & 74.12 & -5.58 & 137,234 \\
\hline Residential advisors (4640) & 67.17 & 60.39 & -6.78 & 101,390 \\
\hline Counter and rental clerks $(4740)$ & 61.55 & 54.06 & -7.49 & 118,672 \\
\hline Models, demonstrators, and product promoters (4900) & 80.27 & 70.01 & -10.26 & 114,274 \\
\hline $\begin{array}{l}\text { First-line supervisors/managers of office and administrative } \\
\text { support workers }^{b}(5000)\end{array}$ & 67.84 & 62.46 & -5.38 & $1,573,769$ \\
\hline Procurement clerks (5150) & 64.78 & 59.36 & -5.42 & 41,916 \\
\hline Tellers $(5160)$ & 89.84 & 85.43 & -4.41 & 470,665 \\
\hline Credit authorizers, checkers, and clerks (5230) & 78.25 & 72.73 & -5.52 & 53,096 \\
\hline Customer service representatives (5240) & 71.02 & 66.59 & -4.43 & $3,323,067$ \\
\hline File clerks $(5260)$ & 79.56 & 74.23 & -5.33 & 438,820 \\
\hline Loan interviewers and clerks (5330) & 85.52 & 78.47 & -7.05 & 145,375 \\
\hline New account clerks $(5340)$ & 84.86 & 76.09 & -8.77 & 17,669 \\
\hline Correspondence clerks and order clerks (includes 5210$)^{b}(5350)$ & 65.11 & 60.96 & -4.15 & 164,699 \\
\hline $\begin{array}{l}\text { Reservation and transportation ticket agents and travel clerks } \\
(5410)\end{array}$ & 67.18 & 60.67 & -6.51 & 153,952 \\
\hline Data entry keyers $(5810)$ & 81.78 & 76.53 & -5.25 & 489,846 \\
\hline Word processors and typists $(5820)$ & 91.91 & 86.02 & -5.89 & 448,222 \\
\hline Statistical assistants $(5920)$ & 67.78 & 61.12 & -6.66 & 25,078 \\
\hline Electrical, electronics, and electromechanical assemblers (7720) & 61.10 & 48.68 & -12.42 & 174,016 \\
\hline Sewing machine operators $(8320)$ & 81.24 & 76.58 & -4.66 & 264,785 \\
\hline $\begin{array}{l}\text { Textile winding, twisting, and drawing out machine setters, } \\
\text { operators, and tenders }(8420)\end{array}$ & 66.71 & 61.94 & -4.77 & 15,955 \\
\hline Packaging and filling machine operators and tenders $(8800)$ & 61.61 & 55.50 & -6.11 & 366,595 \\
\hline Packers and packagers, hand (9640) & 63.56 & 57.07 & -6.49 & 706,881 \\
\hline
\end{tabular}

${ }^{a}$ Feminizing occupations are those in which the percentage point change in the representation of women increased by at least $4 \%$ from 2000 to 2014 .

Masculinizing occupations are those in which the percentage point change in the representation of women decreased by at least $4 \%$ from 2000 to 2014 .

${ }^{\mathrm{b}}$ The titles in 2000 and 2014 were different; we used the 2014 title.

${ }^{c}$ We created a new title.

To enhance comparability with previous work, we organized Table 1 into feminizing occupations (an increase in the representation of women by at least 4 
percentage points) and masculinizing occupations (a decrease in the representation of women by at least 4 percentage points). We further subdivided each into occupations that were initially male in $2000(<40 \%$ female), mixed ( $40 \%-60 \%$ female), and female ( $>60 \%$ female). This presentation allows us to determine which occupations feminized and which masculinized by initial sex type. ${ }^{10}$

The first thing to note is that unlike the post-1970 period, approximately equal numbers of occupations feminized $(n=62)$ as masculinized $(n=61)$. This suggests a level of flux that one might not expect if we assume a stall in overall occupational integration. To assess how many persons are in disproportionately feminizing and masculinizing occupations, we include in Table 1 the number of persons employed in each detailed occupation in 2014. The data shows that $35,166,084$ people worked in the 123 disproportionately changed occupations, $37.7 \%$ in feminizing occupations and $62.3 \%$ in masculinizing occupations. Thus, while approximately equal numbers of occupations feminized as masculinized, many more persons in disproportionate occupations were in masculinizing than feminizing occupations. It's also important to recognize that most persons in 2014 were not in disproportionately changing occupations: Although approximately one-quarter of all detailed occupations changed disproportionately, $19 \%$ of all persons were in disproportionately changing occupations, compared with $81 \%$ in stable occupations.

Our feminizing male occupations $(n=41)$ are comparable to the 33 feminizing occupations in Reskin and Roos's (1990) Table 1.6. Another set of mixed occupations $(\mathrm{n}=14)$ feminized as well, and seven female occupations further feminized. From 2000 to 2014, women continued to make inroads into traditionally male professions and managerial occupations, a process similar to that occurring in the 1970s. The female surge into health-related professions between 2000 and 2014 extends the inroads women made into pharmacy in the 1970s and 1980s (Phipps 1990). Indeed, by 2000 pharmacy was a mixed occupation that further feminized by 2014 . Other health professions feminized: Dentists, optometrists, and veterinarians all increased their representation of women by over $10 \%$, and chiropractors, physicians and surgeons, podiatrists, and other health-diagnosing and treating practitioners by over $5 \%$. These gains reflect in part women's increased representation in postgraduate education (Blau and Kahn 2016; Buchmann, DiPrete, and McDaniel 2008). Despite their inroads between 2000 and 2014, however, by the latter year women were the majority sex in the health professions only among veterinarians (55\% female in 2014).

A few other non-health occupations showed gains: Among feminizing male occupations, natural sciences managers; ushers, lobby attendants, and ticket takers;

\footnotetext{
${ }^{10}$ It also allows easier comparisons with Reskin and Roos's (1990) Table 1.6, which includes sex segregated occupations in which the other sex gained disproportionate entry (male occupations that feminized [ $\mathrm{n}=33]$ and female occupations that masculinized $[n=3]$ ).
} 
agricultural inspectors; and print binding and finishing workers all showed gains of at least $10 \%$. Among feminizing mixed occupations, only animal trainers increased by at least $10 \%$. Finally, two traditionally female occupations feminized by at least $10 \%$ (health diagnosing and treating practitioners and brokerage clerks).

Table 1 clearly supports previous findings that women have not made inroads into skilled or semiskilled production work (England 2010). Male blue-collar work ${ }^{11}$ that disproportionately changed typically masculinized, not feminized: Of the 32 disproportionately changing blue-collar occupations, only six feminized.

In comparison with Reskin and Roos's (1990) findings, the sheer number of masculinizing female occupations increased ( $\mathrm{n}=28$ vs. Reskin and Roos's three occupations), although it is important to point out that initially male and mixed occupations masculinized as well $(n=20$ and $n=13$ respectively). Only two female occupations masculinized by at least 10\%: (1) models, demonstrators, and product promoters and (2) electrical, electronics, and electromechanical assemblers (and it's only in the latter that the 2014 female percentage falls below 50\%). The female occupations that masculinized contain no professional occupations, which is further evidence that men are not making large inroads into what have often been called the female professions (e.g., teaching, social work, nursing, and librarianship). ${ }^{12}$

\subsection{The social demography of feminizing and masculinizing occupations}

We turn to our second research question, on occupational succession: What is the social demography of occupational integration? Since our major independent variable for this initial analysis is integration status (feminizing, stable, and masculinizing) between 2000 and 2014, we focus only on the latter year. Table 2 summarizes our initial descriptive results. We focus on race and immigrant status, but present data more broadly for a selection of variables representing the social and demographic characteristics of the labor force. Our intention here is to be illustrative, not exhaustive.

Looking first at column 1 for all occupations, we see the social and demographic characteristics for the overall workforce. The mean age is 42 , and $48 \%$ are currently

11 We include in this category occ2014 codes 6200 to 9750: construction and extraction occupations; installation, maintenance, and repair workers; production occupations; and transportation and material moving occupations.

${ }^{12}$ We reran Table 1 with a larger cut point $(7 \%$, or 20 times the change in percentage point female from 2000 to 2014), and the results were quite similar. Not surprisingly, the number of disproportionate occupations declined to 37 , with more feminizing than masculinizing occupations (22 vs. 15). As was true for the $4 \%$ cut points, even though more disproportionate occupations feminized than masculinized, more persons were in masculinizing than feminizing occupations. Our other substantive interpretations remained with the larger cut point: women surged into health-related professions; blue-collar work typically masculinized, not feminized; and the female occupations that masculinized contained no classic professions. 
married living with their spouse. Three-quarters of the labor force is white, with substantial percentages of black (12\%) and Hispanic (15\%). The vast majority are US citizens (92\%), with 17\% foreign-born. Only 4\% speak English not well or not at all, but a troubling $12 \%$ are below the poverty level, consistent with recent reports of high levels of inequality in the United States (Jank and Owens 2012). A bit less than onethird (31\%) have four or more years of college, $37 \%$ work in professional or managerial occupations, $91 \%$ work for wages, and approximately two-thirds of workers usually work for wages in reference week and work 50 to 52 weeks last year.

Table 2: Social demographic characteristics of feminizing, stable, and masculinizing occupations, 2014

\begin{tabular}{lcccc}
\hline & \multicolumn{2}{c}{ 2014 } & & \\
\hline Variables & All occupations & Feminizing $^{\mathbf{a}}$ & Stable $^{\mathbf{b}}$ & Masculinizing $^{\mathbf{c}^{\mathbf{y}}}$ \\
\hline Mean age (in years) & 42.4 & 45.7 & 42.4 & 40.5 \\
Percent currently married with spouse & 48.4 & 61.2 & 48.2 & 41.6 \\
Percent white & 75.5 & 80.6 & 75.7 & 70.7 \\
Percent black & 11.7 & 7.5 & 11.7 & 14.6 \\
Percent Hispanic & 15.4 & 8.8 & 15.6 & 18.6 \\
Percent US citizen & 91.8 & 94.8 & 91.8 & 89.8 \\
Percent foreign-born & 17.4 & 15.2 & 17.3 & 19.6 \\
Percent speaking English not well or not at all & 4.3 & 1.3 & 4.2 & 6.6 \\
Percent below poverty level & 12.4 & 5.7 & 12.6 & 15.1 \\
Percent with four or more years of college & 30.6 & 62.8 & 29.6 & 17.7 \\
Percent working in professional or managerial & & & & \\
occupations & 36.9 & 73.7 & 37.2 & 12.2 \\
Percent working for wages in ref day/week & 90.6 & 85.1 & 90.1 & 96.8 \\
Percent usually working 35 or more hours per & & & & \\
week in previous year & 66.4 & 76.6 & 65.6 & 66.2 \\
Percent working 50-52 weeks last year & 65.5 & 75.8 & 64.9 & 63.5 \\
\hline
\end{tabular}

${ }^{a}$ Feminizing occupations are those in which the percentage point change in the representation of women increased by at least $4 \%$ from 2000 to 2014.

${ }^{b}$ Stable occupations are those in which the percentage point change in the representation of women is less than $4 \%$ from 2000 to 2014.

${ }^{\mathrm{C}}$ Masculinizing occupations are those in which the percentage point change in the representation of women decreased by at least $4 \%$ from 2000 to 2014 .

Note: All proportions reported as percentages for presentation purposes.

The more intriguing results emerge when we cross-classify these variables by whether occupations feminized, masculinized, or remained stable between 2000 and 2014. We use these social and demographic characteristics to address the types of workers in feminizing and masculinizing occupations. The results are clear-cut and replicate Gatta and Roos's (2005) findings for earlier decades. In 2014, those in feminizing as opposed to masculinizing occupations are more likely to be white, US citizens, college educated, currently married/with spouse, working full time (both in the 
number of hours and in weeks worked), and working in professional/managerial occupations. For each of these variables, the percentages are highest for feminizing occupations and decline across the row (e.g., to stable and masculinizing occupations). Masculinizing occupations contain a higher percentage of black, Hispanic, and foreignborn people, those speaking English not at all or not well, working for wages (rather than self-employed), and below the poverty level. For these variables, the highest percentages are in the masculinizing column and decline as one moves to the left (to feminizing occupations). ${ }^{13}$

\subsection{Who works in feminizing vs. masculinizing occupations?}

Our final analysis on occupational succession addresses how social demographic characteristics affect who works in feminizing and masculinizing occupations. Thus integration is our dependent variable. The data demonstrates that occupational change is strongly patterned by race and other sociodemographic characteristics. Tables 3 and 4 present results for a logistic regression of occupational integration for 2014. We include in these models only those persons in the 123 occupations that changed disproportionately. We first present the means for our models, separately for total, males, and females (Table 3), and then the multivariate logistic regression estimates, for total, males, and females (Table 4). ${ }^{14}$

Table 3 shows that workers in disproportionately changing occupations had an average age of 42 ; approximately $62 \%$ worked in masculinizing occupations. The modal marital status was married and living with their spouse (49\%), most were citizens $(92 \%)$, and white $(74 \%$ of the sample vs. $12 \%$ and $14 \%$ who were black and other/multiracial respectively). There were sizable minorities who were Hispanic (15\%), foreign-born (18\%), below poverty $(12 \%)$, and those with poor English language proficiency $(5 \%)$. A little over one-third of the sample had four or more years of college (35\%), and $35 \%$ worked in professional or managerial occupations. A full $92 \%$ worked for wages (as opposed to self-employment), $70 \%$ usually worked 35 or

${ }^{13}$ We reran Table 2 with the $7 \%$ cut point for disproportionate occupations, and the results were nearly identical. The one difference was for percent foreign born: with the $7 \%$ cut point, $22 \%$ of those in feminizing occupations were foreign born, compared with $19 \%$ in masculinizing occupations (the $4 \%$ cut point yielded $15 \%$ and $20 \%$, respectively).

${ }^{14}$ Our multivariate analysis is modeled on Gatta and Roos's (2005) multinomial logit, although we simplify the comparison to masculinizing vs. feminizing occupations. Hence, we rely on logistic regression. Our findings are reassuringly similar to Gatta and Roos's (2005), giving us confidence in our analytic choice. We also estimated a multinomial logit of our data and compared our substantive findings from logistic regression (a two-category dependent variable: masculinizing to feminizing) to those of the multinomial logit (a threecategory dependent variable: masculinizing to feminizing, and stable to feminizing). Our results were nearly identical. 
more hours per week, and $68 \%$ worked 50 to 52 weeks in the previous year. Focusing on sex differences, men were more likely than women to be married with their spouse present ( 52 vs. $46 \%$ ), have four or more years of college (38 vs. $31 \%$ ), and work full time (either hourly or weeks worked; $75 \%$ vs. $65 \%$ and $71 \%$ vs. $65 \%$ respectively). Women, on the other hand, were more likely than men to be formerly married ( $23 \%$ vs. $14 \%)$, to be in poverty ( $13 \%$ vs. $10 \%)$, and to be in masculinizing occupations ( $66 \%$ vs. $59 \%)$.

Table 3: Means for a model of occupational integration, US men and women in disproportionately changed occupations, 2013-2014

\begin{tabular}{llll}
\hline & & Means & \\
& Total & Male & Female \\
\hline Dependent variable & & & \\
Occupational integration (1=masculinizing, 0=feminizing) & .623 & .592 & .659 \\
Independent variables & & & \\
Age (in years) & 42.5 & 42.5 & 42.4 \\
Marital status & & & \\
$\quad$ Married, spouse present (ref.) & .490 & .515 & .461 \\
Formerly married, separated & .180 & .139 & .227 \\
$\quad$ Never married & .331 & .346 & .313 \\
Race & & & \\
White (ref.) & .744 & .757 & .730 \\
Black & .119 & .109 & .131 \\
Other (including multirace) & .137 & .134 & .139 \\
Hispanic (1=Hispanic) & .149 & .145 & .154 \\
Citizen (1=US citizen) & .917 & .913 & .920 \\
Foreign born (1=foreign born) & .180 & .181 & .178 \\
Poor English ability (1=speaks English not at all, or not well) & .046 & .042 & .051 \\
Poverty (1=below poverty level) & .115 & .105 & .128 \\
Education & & & \\
LT high school & .088 & .088 & .088 \\
High school/some college & .565 & .536 & .600 \\
4 yrs or more of college (ref.) & .347 & .377 & .313 \\
Professional/manager work (1=worked in prof/mgr occupation) & .354 & .405 & .294 \\
Worked for wages (1=worked for wages in ref day/week) & .924 & .905 & .946 \\
Worked 35 or more hours (1=usually worked 35+ hours per week in & & & \\
previous year) & .701 & .748 & .647 \\
Worked 50-52 weeks (1=worked 50-52 weeks last year) & .681 & .708 & .651 \\
\hline
\end{tabular}

${ }^{a}$ Includes only those in occupations whose percentage point representation of women changed disproportionately from 2000 to 2014 , either positively by at least $4 \%$ (feminizing) or negatively by at least $4 \%$ (masculinzing).

In Table 4 we present three multivariate models for 2014, first for the total population, then for males and females separately. We include odds ratios (OR) for ease of interpretation. Given the coding of the integration variable $(1=$ masculinizing 
occupations and $0=$ feminizing occupations), our odds ratios represent the odds of being in a masculinizing vs. feminizing occupation in 2014. Given the large sample size in the IPUMS data, all of the coefficients are significant $(\mathrm{p}<.0001)$.

\section{Table 4: Logistic regression for a model of occupational integration, US men and women in disproportionately changed occupations, 2013-14 ${ }^{\mathrm{a}}$}

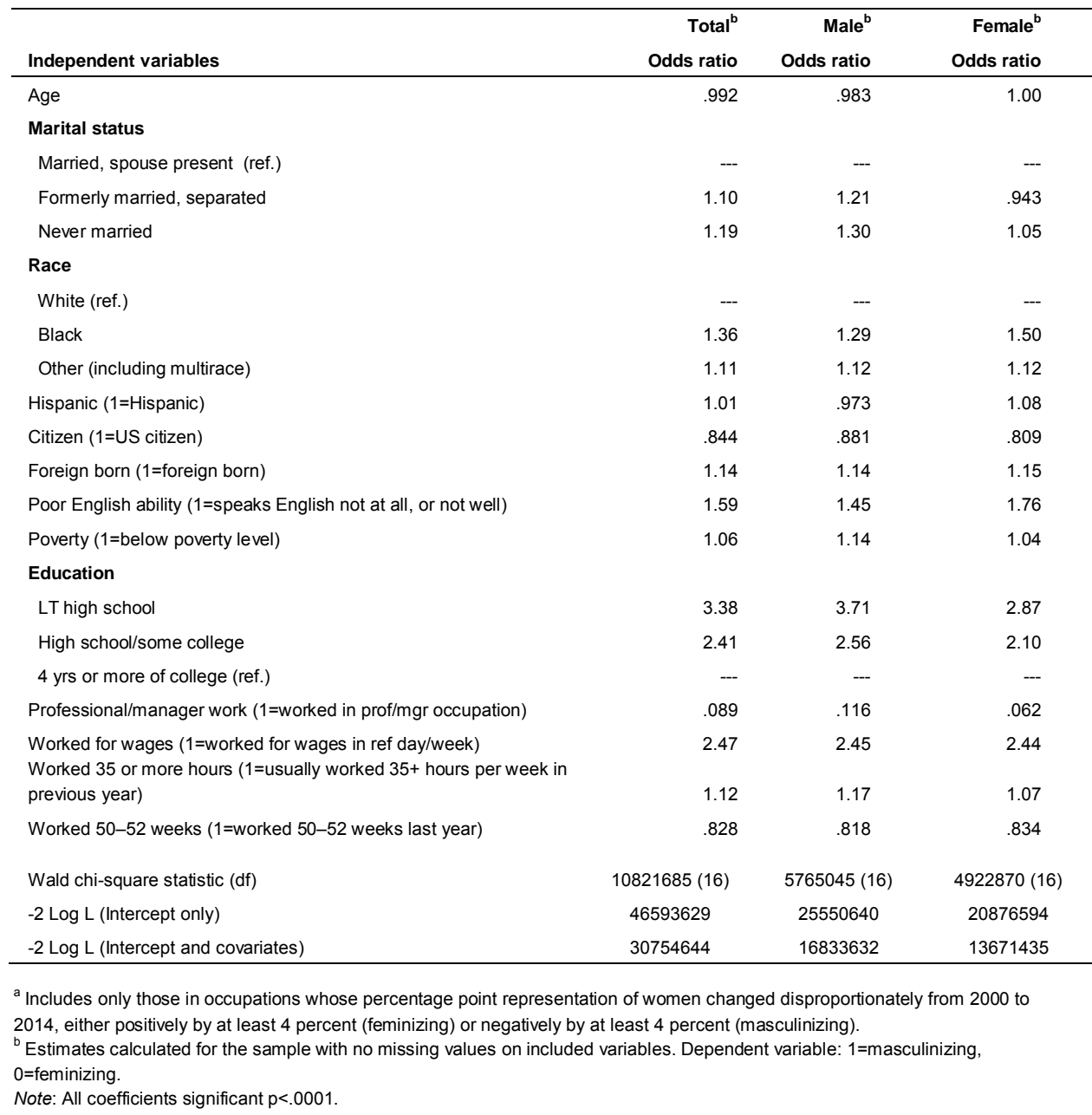


The multivariate results replicate our descriptive findings. For the total population, those respondents with personal variables typically associated with marginal labor market location are more likely to be in masculinizing occupations (odds ratios greater than 1). Those with characteristics typically associated with higher labor market rewards are more likely to be in feminizing occupations (odds ratios less than 1). Nonwhites (either black or other races) are significantly more likely to be in masculinizing occupations. In comparison to whites, blacks have 1.36 times the odds, and other races 1.11 times the odds, of being in masculinizing occupations. Similarly, those who are foreign-born $(\mathrm{OR}=1.14)$, who have poor English speaking skills $(\mathrm{OR}=1.59)$, or have never married $(\mathrm{OR}=1.19$, relative to married $)$ are more likely to work in masculinizing occupations. In comparison with college graduates, those with less than a high school diploma or high school/some college are significantly more likely to be in masculinizing occupations ( $\mathrm{OR}=3.38$ and $\mathrm{OR}=2.41$ respectively). In contrast, citizens, those in professional or managerial work, and those working 50 to 52 weeks per year are more likely to work in feminizing occupations $(\mathrm{OR}=.844$, $\mathrm{OR}=$ .089 , and $\mathrm{OR}=.828$, respectively). Full-time hours is associated with working in masculinizing occupations $(\mathrm{OR}=1.12)$.

Our remaining logistic regressions investigate whether the factors affecting the odds of being in a masculinizing vs. feminizing occupation vary by sex. Many of the variables we specified are associated with masculinization for men, including being black or other race relative to white, being foreign-born, having poor English speaking skills, being in poverty, having less than a college degree relative to college graduation, working for wages and full-time hours, and being formerly or never married relative to married. Intriguingly, the variables that predicted working in a masculinizing occupation were similar for women, although not identical: being black or other race relative to white, being foreign-born, having a poor English speaking ability, having less than a college degree relative to college graduation, working for wages and fulltime hours, and being never married relative to married. Being Hispanic increased the odds of working in masculinizing occupations for women but increased the odds of working in feminizing occupations for men $(\mathrm{OR}=1.08 \mathrm{vs}$. $\mathrm{OR}=.973)$. The only other sex difference was being formerly married relative to married increased the odds of working in masculinizing occupations for men, but was linked to feminization for women. For both men and women, being white, non-Hispanic, educated, US born, and citizens (among other characteristics) worked to advantage workers' inroads to feminizing occupations. 


\section{Discussion}

Our data provides novel insights into how occupational integration unfolded in the beginning decades of the $21^{\text {st }}$ century. We summarize our results here, by returning to our two research questions. First, it's important to recognize that while a stall in occupational desegregation can exist at the level of the labor market as a whole, there can still be considerable flux in the shifting gender makeup of individual occupations. The 2000 to 2014 period continued some of the feminizing trends we saw in the 1970 to 2000 period, including continuing inroads for women into traditionally male health professions.

We also find that masculinization was more common between 2000 and 2014 than it was in earlier years. Although much of the earlier research on men's entry into occupations examines the female professions (e.g., nursing, social work, librarianship, and teaching; Lupton 2006; Williams 2013; Wingfield 2009), our data suggests that these were not the occupations that disproportionately masculinized. Instead, men increased their representation in lower status, nonprofessional occupations. ${ }^{15}$

Second, we examine the social-demographic characteristics of those located in feminizing and masculinizing occupations. The results are unequivocal: Those in feminizing occupations are more likely to be white, US citizens, educated, currently married/with spouse, working in a professional/managerial occupation, and working full time (in hours and weeks worked). Those in masculinizing occupations are more likely to be black, Hispanic, persons speaking English poorly, working for wages (as opposed to self-employed), foreign-born, and in poverty.

Our multivariate results predicting 2014 occupational placement underscore that women have continued their inroads into traditionally male occupations much in the same way that they did in the immediate post- 1970 period. What has changed after 2000 is that there is movement toward masculinization as well as feminization. Masculinization, however, is not fueled by the occupational movement of all men. Instead, it occurs among those marginal to the labor market - nonwhites, foreign-born, noncitizens, the less educated, those in poverty, and those with poor English speaking skills.

What conclusions can we draw from our findings and what insights can they provide about occupational integration? As noted, our data cannot speak to the issue of choice, or to the relative importance of egalitarianism-driven vertical vs. essentialismdriven horizontal integration (Charles and Bradley 2009; Charles and Grusky 2004; see

${ }^{15}$ If the number of years examined were to be broadened beyond 2000 to 2014 , there would be a larger increase of nurses: Between 1970 and 2011, men's representation among registered nurses increased from $2.7 \%$ to $9.6 \%$, and among licensed practical/vocational nurses from $3.9 \%$ to $8.1 \%$ (Landivar 2013: 2). Nursing is still, however, heavily female. See also Miller and Fremson (2018) and Munnich and Wozniak (2017). 
also England 2016). We can only know occupational outcomes in 2000 and 2014, not the choices that got workers to those occupations. Building the historical record, however, adds new data to the long conversation on occupational feminization that gained new momentum in the 1970s.

One aspect of that conversation was whether women's inroads into male occupations constituted genuine integration, ghettoization, or resegregation (Reskin and Roos 1990: Chapter 3). At any particular point in time, we do not know whether feminization (or masculinization) will continue, reverse, or remain stable. Are feminizing occupations on a path toward genuine integration, will women become ghettoized into fields within feminizing occupations, or will these occupations resegregate as female? We are unable to fully answer these questions. We can say, however, that in most of the feminizing occupations in Table 1, women were not in 2000, and still are not in 2014, equally represented with men. For example, women were $18 \%$ of dentists in 2000 and $28 \%$ in 2014 (still a male occupation by our terminology). Optometrists were $27 \%$ female in 2000 , increasing to $41 \%$ in 2014 (moving it to a mixed occupation). In pharmacy, women topped 55\% by 2014 (still a mixed but perhaps beginning to resegregate as female). Several health professions were already female occupations and continued to further resegregate between 2000 and 2014 , including physician assistants (64\% to 68\%), health diagnosing and treating practitioners $(61 \%$ to $72 \%)$, and opticians $(66 \%$ to $74 \%)$. The only health-care occupation into which men disproportionately increased their representation was radiation therapists, where the percent female declined from $72 \%$ to $65 \%$ (indicating that it is still clearly a female occupation).

We can also add insight into studies of how occupations integrate. Our findings support the argument that it's the unevenness of occupational integration that has grown ever more visible in the 2000 to 2014 period (Reskin and Maroto 2011: 82). We find that changing occupational sex segregation is patterned by race and other sociodemographic characteristics. Of those occupations that have undergone disproportionate feminization, it is whites (relative to nonwhites), US citizens, the college educated, those currently married/with spouse (relative to other marital statuses), those working full-time weeks, and those working in professional $/$ managerial occupations who are more likely to be in feminizing occupations. Our findings confirm that college educated and mostly white women, spurred on by supportive policies such as Title IX, have continued to make inroads into the same types of professional and managerial occupations they gained access to in the immediate post-1970 period. With their increased levels of education and experience, these are women at the top of the labor queue and able to compete with their male counterparts. Expanding beyond their concentration in nursing and pharmacy in the post-1970 period, women have moved 
into other health-related professions - findings consistent with women's increased education levels.

Conversely, Hispanics, nonwhites (relative to whites), those with poor English skills, the foreign-born, those working for wages (vs. self-employed), and those below the poverty line are more likely to be in masculinizing occupations. Our findings are consistent with arguments that addressed the uneven nature of occupational change by examining men's involuntary movement into the service sector and other feminized labor (Dill, Price-Glynn, and Rakovski 2016; Gatta, Boushey, and Appelbaum 2009). Williams and Villemez (1993) find that some men enter predominantly female professions through a "trap door": Men facing disadvantages in the labor market (often poor and/or minority) enter less desirable, often feminized, sectors of the labor market. Lupton (2006) finds that middle-class men in the United Kingdom are guided into professional careers by their families, schools, and guidance counselors, while workingclass men moved into female professions, like library science, human resources, and elementary education.

Importantly, masculinization is not occurring disproportionately in the female professions, suggesting that a broader application of these researchers' theories might be called for. Our findings are also consistent with England's (2010) argument that privileged men, unlike their marginalized counterparts, can resist moving into predominantly female occupations, particularly those that are less prestigious (see McCall 2011).

In sum, this research demonstrates the usefulness of focusing on masculinizing occupations, and not just those women making inroads into predominantly male occupations. Occupational feminization was the big story of the 1970s. Now the story has broadened to race and other sociodemographic characteristics and the role they play in sex integration. We have provided a broader picture of recent trends in occupational integration, moving beyond a focus on predominantly male or female occupations, to examine sex integration in process. Our findings illustrate the importance not just of shifts in sex composition, but also of the importance of race, immigrant status, and other sociodemographic characteristics on occupational integration.

As policy makers digest such findings, it's important to broaden policy solutions beyond a focus on choice. As McCall (2001: 118) argues, public policies need to address the underlying economic conditions that help to create varied "configurations of inequality." To address these forms of inequality requires a more expansive set of policies that ensure access to unions and minimum wage legislation that enhance economic security among low-paid workers. Related to this, future research would also benefit from an examination of how working conditions, such as job satisfaction, wages, and/or benefits, shift over time, either similarly or differently for women and men, and/or for feminizing and masculinizing occupations. 


\section{Acknowledgements}

We thank Mary Gatta, Deborah Carr, Dana Britton, Paula England, Leslie McCall, Julie Phillips, and anonymous reviewers for advice on previous versions. This article was supported in part by a Rutgers University Research Council Grant, AY 2013-14. We presented an earlier version of the paper at the American Sociological Association Annual Meetings, August, 2014. 


\section{References}

Alegria, S.N. and Branch, E.H. (2015). Causes and consequences of inequality in the STEM: Diversity and its discontents. International Journal of Gender, Science and Technology 7(3): 321-342.

Autor, D. (2010). The polarization of job opportunities in the U.S. labor market [electronic resource]. Washington, D.C.: The Hamilton Project. http://www.hamiltonproject.org/papers/the_polarization_of_job_opportunities_i n_the_u.s._labor_market_implica.

Blau, F.D. and Kahn, L.M. (2016). The gender wage gap: Extent, trends, and explanations. Bonn: Institute for Labor (IZA) (IZA discussion paper 9656). http://ftp.iza.org/dp9656.pdf.

Branch, E.H. (2011). Opportunity denied: Limiting black women to devalued work. New Brunswick: Rutgers University Press.

Britton, D. (2000). The epistemology of the gendered organization. Gender and Society 14(3): 418-434. doi:10.1177/089124300014003004.

Browne, I. and Misra, J. (2003). The intersection of gender and race in the labor market. Annual Review of Sociology 29: 487-513. doi:10.1146/annurev.soc.29.010202. 100016.

Buchmann, C., DiPrete, T.A., and McDaniel, A. (2008). Gender inequalities in education. Annual Review of Sociology 34: 319-337. doi:10.1146/annurev.soc. 34.040507.134719.

Charles, M. and Bradley, K. (2009). Indulging our gendered selves? Sex segregation by field of study in 44 countries. American Journal of Sociology 114(4): 924-976. doi:10.1086/595942.

Charles, M. and Grusky, D. (2004). Occupational ghettos: The worldwide segregation of women and men. Stanford: Stanford University Press.

Cohen, P.N. (2013, November 23). How can we jump-start the struggle for gender equality? New York Times: SR9. https://opinionator.blogs.nytimes.com/2013/ 11/23/how-can-we-jump-start-the-struggle-for-gender-equality/?_r $=0$

Cohen, P.N., Huffman, M.L., and Knauer, S. (2009). Stalled progress? Gender segregation and wage inequality among managers, 1980-2000. Work and Occupations 36(4): 318-342. doi:10.1177/0730888409347582. 
Cotter, D.A., Hermsen, J.M., and Vanneman, R. (2004). Gender inequality at work. New York: Russell Sage Foundation.

Cotter, D.A., Hermsen, J.M., and Vanneman, R. (2009). The stalled gender revolution [electronic resource]. College Park: University of Maryland. http://www.bsos. umd.edu/socy/vanneman/endofgr/default.html.

Coontz, S. (2011). A strange stirring: The feminine mystique and American women at the dawn of the 1960s. New York: Basic Books.

Dewan, S. and Gebeloff, R. (2012, May 20). More men enter fields dominated by women. New York Times: A1. http://www.nytimes.com/2012/05/21/business/ increasingly-men-seek-success-in-jobs-dominated-by-women.html.

Dill, J.S., Price-Glynn, K., and Rakovski, C. (2016). Does the 'glass escalator' compensate for the devaluation of care work occupations? The careers of men in low- and middle-skill health care jobs. Gender and Society 30(2): 334-360.

England, P. (2010). The gender revolution: Uneven and stalled. Gender and Society 24(2): 149-166. doi:10.1177/0891243210361475.

England, P. (2016). Sometimes the social becomes personal: Gender, class, and sexualities. American Sociological Review 81(1): 4-28. doi:10.1177/00031224 15621900 .

Gatta, M.L., Boushey, H., and Appelbaum, E. (2009). High-touch and here to stay: Future skills demands in U.S. low wage service occupations. Sociology 43(5): 968-989. doi:10.1177/0038038509340735.

Gatta, M.L. and Roos, P.A. (2005). Rethinking occupational integration. Sociological Forum 20(3): 369-402. doi:10.1007/s11206-005-6594-5.

Hegewisch, A. and Hartmann, H. (2014). Occupational segregation and the gender wage gap: Job half done. Washington, D.C.: Institute for Women's Policy Research. https://www.dol.gov/wb/resources/occupational_segregation_and_wa ge_gap.pdf.

Jank, S. and Owens, L. (2012) Inequality in the United States: Understanding inequality with data [electronic resource]. Stanford: Stanford Center on Poverty and Inequality. http:/inequality.stanford.edu/sites/default/files/Inequality_SlideDe ck.pdf.

Kalleberg, A.L. (2009). Precarious work, insecure workers: Employment relations in transition. American Sociology Review 74(1): 1-22. doi:10.1177/0003122409 07400101 . 
Kalleberg, A.L. (2011). Good jobs, bad jobs: The rise of polarized and precarious employment systems in the United States, 1970s to 2000s. New York: Russell Sage Foundation.

Landivar, L.C. (2013). Men in nursing occupations: American Community Survey highlight report. Suitland: U.S. Bureau of the Census, Social, Economic, and Housing Statistics Division. https://www.census.gov/people/io/files/Men_in_ Nursing_Occupations.pdf.

Lupton, B. (2006). Explaining men's entry into female-concentrated occupations: Issues of masculinity and social class. Gender, Work and Organizations 13(2): 103128. doi:10.1111/j.1468-0432.2006.00299.x.

Mandel, H. (2013). Up the down staircase: Women's upward mobility and the wage penalty for occupational feminization, 1970-2007. Social Forces 91(4): 11831207. doi:10.1093/sf/sot018.

McCall, L. (2001). Complex inequality: Gender, class and race in the new economy. New York: Routledge.

McCall, L. (2005). The complexity of intersectionality. Signs 30(3): 1771-1800. doi:10.1086/426800.

McCall, L. (2011). Women and men as class and race actors: Comment on England. Gender and Society 25(1): 94-100. doi:10.1177/0891243210389812.

Miller, C.C. (2017, March 9). Race and class define men who take 'women's jobs.' New York Times: B1. https://www.nytimes.com/2017/03/09/upshot/more-menare-taking-womens-jobs-at-least-certain-men.html.

Miller, C.C. and Fremson, R. (2018, January 4). Forget about the stigma: Male nurses explain why nursing is a job of the future for men. New York Times. https://www.nytimes.com/interactive/2018/01/04/upshot/male-nurses.html.

Munnich, E. and Wozniak, A. (2017). What explains the rising share of U.S. men in registered nursing? Working paper series 2017-10, Washington Center for Equitable Growth. http://equitablegrowth.org/working-papers/rising-share-mennursing/.

Phipps, P.A. (1990). Industrial and occupational change in pharmacy: Prescription for feminization. In: Reskin, B.F. and Roos, P.A. (eds.). Job queues, gender queues: Explaining women's inroads into male occupations. Philadelphia: Temple University Press: $111-127$. 
Reskin, B.F. and Maroto, M.L. (2011). What trends? Whose choices? Comment on England. Gender and Society 25(1): 81-87. doi:10.1177/0891243210390935.

Reskin, B.F. and Roos, P.A. (eds.) (1990). Job queues, gender queues: Explaining women's inroads into male occupations. Philadelphia: Temple University Press.

Ruggles, S., Genadek, K., Goeken, R., Grover, J., and Sobek, M. (2015). Integrated public use microdata series: Version 6.0 [dataset]. Minneapolis: University of Minnesota. doi:10.18128/D010.V6.0.

Tomaskovic-Devey, D., Zimmer, C., Stainback, K., Robinson, C., Taylor, T., and McTague, T. (2006). Documenting desegregation: Segregation in American workplaces by race, ethnicity, and sex, 1966-2003. American Sociological Review 71(4): 565-588. doi:10.1177/000312240607100403.

Williams, C.L. (1993). Doing 'women's work': Men in nontraditional occupations. Newbury Park: Sage. doi:10.4135/9781483326559.

Williams, C.L. (2013). The glass escalator, revisited: Gender inequality in neoliberal times. Gender and Society 27(5): 609-629. doi:10.1177/0891243213490232.

Williams, S.L. and Villemez, W.J. (1993). Seekers and finders: Male entry and exit in female dominated jobs. In: Williams, C.L. (ed.). Doing 'women's work:' Men in nontraditional occupations. Newbury Park: Sage Publications: 64-90. doi:10.4135/9781483326559.n5.

Wingfield, A. (2009). Racializing the glass escalator: Reconsidering men's experiences with women's work. Gender and Society 23(1): 5-26. doi:10.1177/0891 243208323054 . 